\title{
Deteksi Daging Sapi Menggunakan Electronic Nose Berbasis Bidirectional Associative Memory
}

\author{
Eviyan Fajar Anggara*1, Triyogatama Wahyu Widodo $^{2}$, Danang Lelono ${ }^{3}$ \\ ${ }^{1}$ Prodi Elektronika dan Instrumentasi, DIKE, FMIPA UGM, Yogyakarta, Indonesia \\ ${ }^{2,3}$ Departemen Ilmu Komputer dan Elektronika, FMIPA UGM, Indonesia \\ e-mail: *1 efajaranggara@gmail.com $^{2}{ }^{2}$ yogatama@mail.ugm.ac.id,${ }^{3}$ danang@ mail.ugm.ac.id
}

Abstrak
E-nose merupakan sebuah instrumen yang digunakan untuk mendeteksi bau atau aroma. E-nose yang dikembangkan dengan algoritma Bidirectional Associative memory (BAM) yang memiliki kelebihan dalam memproses data input yang tidak lengkap dan terdapat noise. Tujuan dari penelitian adalah mengimplementasikan algoritma BAM untuk mendeteksi daging sapi murni diantara sampel daging sapi, daging babi, dan daging campuran dari aromanya dengan sistem e-nose.

Pengolahan data hasil pembacaan sampel dimulai dengan melakukan proses manipulasi baseline untuk membuat nilai baseline menjadi 0, kemudian hasil tesebut dilakukan ekstraksi ciri difference dan integral untuk mendapatkan informasi penting dari masing-masing sampel. Data ekstraksi ciri akan diubah menjadi pola matriks bipolar ( 1 dan -1 ) untuk dapat digunakan sebagai data pada algoritma BAM sehingga diperlukan data threshold untuk dapat menentukan data ektraksi ciri menjadi bipolar. Data yang sudah menjadi matriks bipolar akan digunakan sebagai data uji dan data acuan pada program dengan pengujian cross validation sehingga didapat persentase kebenaran deteksi daging menggunakan e-nose berbasis BAM.

Deteksi daging dengan BAM menggunakan ekstraksi ciri integral dengan bipolar cara pertama menghasilkan persentase keberhasilan 14,8\% dan bipolar cara kedua menghasilkan persentase keberhasilan 15,7\%. Ekstraksi ciri difference dengan bipolar cara pertama menghasilkan persentase keberhasilan 17,3\% dan bipolar cara kedua menghasilkan persentase keberhasilan 16,4\%.

Kata kunci - electronic nose, daging sapi, threshold, bipolar, Bidirectional Associative memory(BAM).

\begin{abstract}
E-nose is an instrument used to detect odor. E-nose developed with Bidirectional Associative memory (BAM) algorithm has advantages in processing incomplete input data and noise. The purpose of the study was to implement the BAM algorithm to detect pure beef among samples of beef, pork, and mixed meat from aroma with e-nose.

Data processing of the sample reading results begins by performing the baseline manipulation process, then do difference and integral feature extraction for the data. The characteristic extraction data will be converted into bipolar matrix patterns (1 and -1) so that the threshold data is needed to be able to determine the feature extraction data to be bipolar. Data that have become bipolar matrices will be used as test and reference data in the program with cross validation testing to obtain the percentage of truth of meat detection using BAM based e-nose.

Detection of meat with BAM using integral feature extraction with bipolar the first way yields a 14,8\% success percentage and the second way bipolar yields a 15,7\% success rate. The extraction of characteristic difference with bipolar the first way yields a success percentage of $17,3 \%$ and the second way bipolar yields a success rate of $16,4 \%$.
\end{abstract}

Keywords - electronic nose, beef, threshold, bipolar, Bidirectional Associative memory(BAM).

Received May $30^{\text {th }}, 2017 ;$ Revised August 30 ${ }^{\text {th }}, 2017$; Accepted October 30 ${ }^{\text {th }}, 2017$ 


\section{PENDAHULUAN}

Kebutuhan konsumsi daging sapi penduduk Indonesia cenderung terus meningkat sejalan dengan meningkatnya jumlah penduduk Indonesia dan kesadaran masyarakat akan pentingnya protein hewani. Laju permintaan daging sapi yang meningkat ini tidak diimbangi oleh peningkatan produksi daging sapi dalam negeri [1]. Permasalahan yang sering terjadi saat ini adalah masyarakat kurang teliti dalam membeli daging bahkan tidak memahami perbedaan antara daging sapi dan babi, sehingga dengan kebutuhan daging sapi yang meningkat sering dimanfaatkan oleh penjual daging di pasar untuk melakukan pencampuran daging sapi dengan daging babi [2].

Bagi Muslim, isu kehalalan makanan merupakan sesuatu yang seringkali berulang. Penanganan akan isu ini lebih banyak bersifat sesaat atau hanya untuk meredam situasi seketika. Padahal, dengan pola konsumsi pangan modern yang semakin kompleks dan bervariasi, penyelesaian secara tuntas menjadi amat penting.Salah satu kendala yang sering dihadapi dalam menangani isu makanan halal adalah ketiadaan metode yang benar-benar ampuh untuk menganalisa substansi tidak halal dalam bahan pangan [3]. Salah satu cara yang sudah dikembangkan untuk mengenali daging sapi yang telah dicampur adalah dengan electronic nose. Electronic nose telah banyak dikembangkan dan diterapkan dalam berbagai bidang diataranya untuk mengenali, mengidentifikasi, dan menganalisa aroma [4]. Salah satu implementasi kemampuan dari electronic nose yang sudah dikembangkan adalah digunakan untuk mengklasifikasikan mutu dari teh hitam lokal. Hasil klasifikasi mutu teh hitam didapatkan dari kinerja electronic nose yang telah dievaluasi dengan sampel yang dipanaskan menggunakan suhu tinggi dan stabil [5].

Jaringan Syaraf Tiruan (JST) merupakan bagian dari machine learning yang mempunyai cara kerja mirip dengan otak manusia yang belajar dari contoh atau data pelatihan yang dipelajarinya untuk dapat mengorganisasi dirinya sendiri. Salah satu algoritma JST adalah Bidirectional Assosiative Memory (BAM). Algoritma ini mempunyai kelebihan dapat memproses data input yang tidak lengkap dan terdapat noise [6].

Algoritma ini telah digunakan untuk membantu proses deteksi wajah pada sistem absensi yang menggunakan wajah sebagai masukannya [7]. Namun algoritma ini belum pernah diimplementasikan pada electronic nose sehingga pada penelitian ini diharapkan algoritma BAM dapat diimplementasikan dalam proses deteksi daging sapi murni diantara sampel daging sapi, daging babi, dan daging campuran.

\section{METODE PENELITIAN}

\subsection{Analisis Sistem}

Laboratorium riset Elektronika dan Instrumentasi UGM telah mengembangkan electronic nose semi terbuka menggunakan 5 sensor, yaitu terdiri dari TGS 2610, TGS 2602, TGS 2620, TGS 2611, TGS 2600 [8]. Penanganan sampel berdasarkan aroma dengan menggunakan electronic nose perlu dianalisis lebih lanjut dengan mengidentifikasi hasil menggunakan mesin pengenal pola. Sekilas memang aroma bisa dibedakan dengan hidung secara langsung namun tetap masih tergantung oleh ketajaman penciuman oleh manusia itu sendiri sehingga meskipun aroma spesifik namun tidak dapat dideteksi secara detail oleh hidung manusia karena harus melalui latihan yang berulang-ulang. Kontributor penting dalam pemberi bau khas daging sapi dan daging babi adalah jaringan lemak dalam daging [9]. Pada produk olahan campuran dari sapi dan babi, bau yang lebih dominan berasal dari jaringan tanpa lemak salah satu dari kedua spesies tersebut dimana komposisi yang lebih besar akan memberikan bau yang lebih dominan [10]. Berdasarkan referensi tersebut apabila dalam pencampuran antara daging sapi dan daging babi memiliki proporsi yang sama maka bau atau aroma akan sulit diidentifikasi. Oleh karena itu ketika terjadi pencampuran diharapkan mempunyai perbedaan pola yang bisa dihasilkan dari kemampuan electronic nose menggunakan algoritma BAM. Kekuatan BAM adalah memiliki kemampuan associative memory, yaitu memory yang dapat dipanggil menggunakan bagian informasi yang tersimpan didalamnya [6]. Kemampuan

IJEIS Vol. 7, No. 2, October 2017 : $209-218$ 
associative memory yang dimiliki BAM mempunyai hubungan dengan respon sensor ataupun dengan fitur ekstraksinya. Hal ini dikarenakan respon sensor adalah merupakan hasil dari pengujian menggunakan electronic nose dan kemudian diolah melalui normalisasi baseline, ekstraksi ciri, pengubahan ke bipolar. Hasil akhir adalah berupa sekumpulan matriks bipolar yang dapat disimpan oleh associative memory dengan cara menjumlahkan matriks korelasi bipolar.

\subsection{Perancangan Sistem}

\subsubsection{Preparasi Data}

Data penelitian ini terdiri dari data sampel daging sapi, data daging babi, data daging campuran babi $20 \%$, data daging campuran babi $40 \%$, data daging campuran babi $60 \%$, dan data daging campuran babi $80 \%$. Data-data tersebut memuat informasi pembacaan dari 5 sensor yaitu TGS 2600, TGS 2602, TGS 2610, TGS 2611, dan TGS 2610. Masing-masing sampel ada 3 data hasil pengambilan data sehingga keseluruhan data berjumlah 18 data.

\subsubsection{Pengolahan Data}

Pengolahan data dilakukan dalam beberapa tahapan yaitu nomalisasi baseline dan ekstraksi ciri. Setiap hasil pengambilan data untuk masing-masing sampel didapatkan nilai minimum dan nilai maksimum puncak dari data sensor, dari nilai tersebut maka digunakan dalam proses normalisasi baseline. Metode normalisasi baseline yang menggunakan persamaan 1 .

$$
Y_{n \prime}=Y_{n}-Y_{1}
$$

dimana $Y_{n}$ merupakan nilai tegangan data sensor dan $Y_{l}$ merupakan nilai tegangan pertama atau nilai tegangan terendah dari data yang didapat [11]. Metode ekstraksi ciri yang dilakukan menggunakan metode integral dan difference. Metode ekstraksi ciri integral yaitu dengan menghitung luasan kurva sinyalnya. Sedangkan metode difference yaitu dengan menghitung rentang nilai respon sensor terendah dan tertingginya. Data yang sudah diperoleh dari kedua metode ekstraksi ciri tersebut kemudian di proses untuk diubah menjadi bipolar berupa 1 dan -1 yang akan membentuk pola matriks dari masing-masing sampel. Data untuk dapat diproses dengan BAM berupa biner (1 dan 0) atau bipolar (1 dan -1) [12].Data ini kemudian digunakan untuk pelatihan dan pengujian dari sistem algoritma Bidirectional Associative memory (BAM).

\subsubsection{Rancangan Program}

Rancangan program dimulai dengan memasukan data hasil ekstraksi ciri yang akan digunakan untuk pelatihan dan pengujian serta data yang sudah ditentukan sebagai targetnya. Data hasil ekstraksi ciri merupakan data yang didapatkan dari pembacaan sensor-sensor electric nose dari keenam sampel, selanjutnya masing-masing data tersebut dilakukan proses normalisasi baseline yang bertujuan untuk menyamakan titik awal dari masing-masing sensor pada titik 0. Hal ini dilakukan untuk menghindari adanya data bacaan sensor yang terlalu menyimpang, yang diakibatkan dari faktor-faktor seperti kesalahan pembacaan sensor, perubahan udara dari lingkungan. Langkah selanjutnya data hasil normalisasi baseline dilakukan proses ekstraksi ciri. Dalam penelitian ini ekstraksi ciri dilakukan dengan 2 metode yaitu ekstraksi ciri integral dan ekstraksi ciri difference. Proses ekstraksi ciri ini bertujuan untuk mengambil informasi penting dari keseluruhan data hasil pembacaan sensor. Informasi penting hasil ekstraksi ciri ini mewakili karakteristik dari data sampelnya. Hasil ekstraksi ciri ini akan membentuk matriks $7 \times 5$ karena terdiri dari 5 macam yang tiap sensornya ada 7 gelombang yang kemudian ditentukan nilai threshold untuk masing-masing sampel. Nilai dari threshold ini akan dijadikan pembatas dalam mengubah nilai ekstraksi ciri dari masing-masing data sampel menjadi bipolar yaitu 1 dan -1 .

Proses penentuan threshold untuk mengubah hasil ekstraksi ciri menjadi bipolar ini dilakukan dengan 2 cara sebagai berikut: 
1. Cara menentukan nilai threshold dalam penelitian ini dilakukan dengan mencari rata-rata tiap sensor dari sampel acuan. Selanjutnya setiap sensor akan mempunyai nilai rata-rata tertinngi dan terendah dari sampel acuannya, dari nilai tersebut didapatkan nilai jangkauan. Nilai jangkauan ini kemudian dicari nilai tengahnya, yang akan ditambahkan dengan nilai rata-rata terendah dari setiap sensor. Hasil penambahan antara nilai tengah jangkauan dengan nilai terendah dari setiap sensor inilah yang dijadikan nilai threshold.

2. Cara menentukan nilai threshold dengan mencari rata-rata tiap sensor dari keseluruhan sampel acuan, kemudian hasil rata-rata masing-masing sensor digunakan untuk dijadikan nilai threshold.

Proses penentuan threshold dilakukan dengan 2 cara ini untuk mengetahui pengaruh nilai threshold yang digunakan untuk menentukan nilai bipolar dalam hasil deteksi yang dilakukan menggunakan program BAM.

Nilai hasil ekstraksi ciri yang berada diatas nilai threshold akan dinyatakan bernilai 1 , sedangkan yang berada dibawah nilai threshold dinyatakan bernilai -1. Dalam perubahan menjadi bipolar ini berlaku untuk semua data hasil ekstraksi ciri integral maupun difference. Sehingga setelah diubah menjadi bipolar maka akan terbentuk matriks pola yang mencirikan suatu sampel. Matriks bipolar pola sampel ini akan digunakan untuk data input ke sistem algoritma Bidirectional Associative memory yang dibuat. Algoritma BAM ini akan mendeteksi data uji bedasarkan data pelatihannya untuk membedakan daging sapi murni dengan daging babi dan daging sapi campuran. Hasil deteksi daging sapi ini merupakan akhir dari proses penelitian.

\subsection{Rancangan Pengujian}

Pengujian dilakukan untuk mengetahui hasil deteksi daging sapi yang dilakukan oleh sistem yang dibuat. Ada 2 pengujian yang dilakukan dalam penelitian ini.

\subsubsection{Pengujian Algoritma dengan Menggunakan Data Referensi}

Pengujian algoritma dengan menggunakan data dari referensi ini bertujuan untuk menunjukkan bahwa sistem yang dibuat sudah sesuai dengan algoritma Bidirectional Associative Memory.

\subsubsection{Pengujian Deteksi Keseluruhan Daging Sapi dari Ekstraksi Ciri Derivatif dan Integral}

Pengujian ini bertujuan mengetahui nilai keberhasilan sistem yang dibuat untuk mendeteksi daging sapi diantara sampel yang lainnya. Pada pengujian ini juga digunakan proses ekstraksi ciri intergral dan difference sehingga akan terlihat perbandingan antara keduanya. Proses pengujian dilakukan dengan cross validation, yang berarti pengujian dilakukan menggunakan semua data sebagai data acuan dan data ujinya. Pada proses pengujian cross validation ini, setiap data uji tidak boleh ada pada data acuan. Pengujian akan dilakukan sebanyak 8748 kali dengan 729 data acuan. Sehingga akan didapatkan persentase tingkat kebenaran deteksi yang sesuai dengan data ujinya dari sistem yang dibuat.

\section{HASIL DAN PEMBAHASAN}

\subsection{Pengujian Respon Sensor}

Pengujian respon sensor ini bertujuan untuk mengetahui nilai respon dari masingmasing sensor $e$-nose yang digunakan saat pengujian sampel. Nilai respon sensor dari 5 sensor gas elektronik yang digunakan ditampilkan dalam bentuk tegangan $(\mathrm{mV})$ yang didapatkan tiap satuan waktu detik (s), sehingga grafik yang dihasilkan respon sensor terhadap waktu, seperti yang ditunjukkan oleh Gambar 1. 


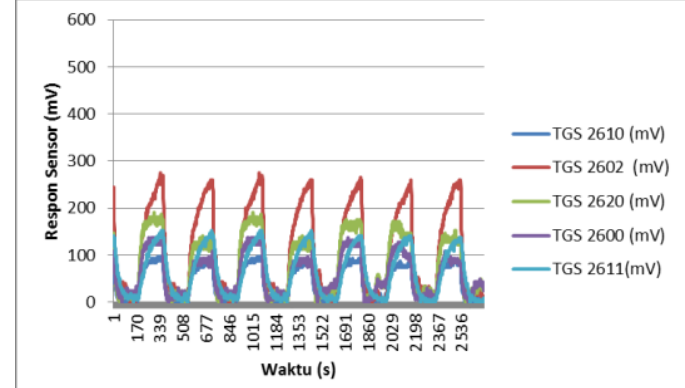

(a)

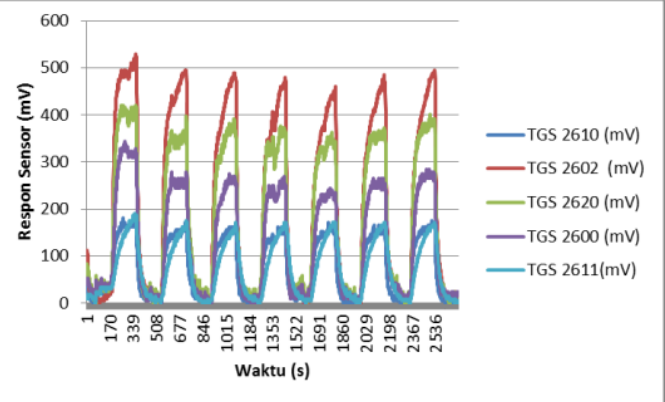

(b)

Gambar 1 Grafik respon sensor daging sapi (a) dan daging babi (b)

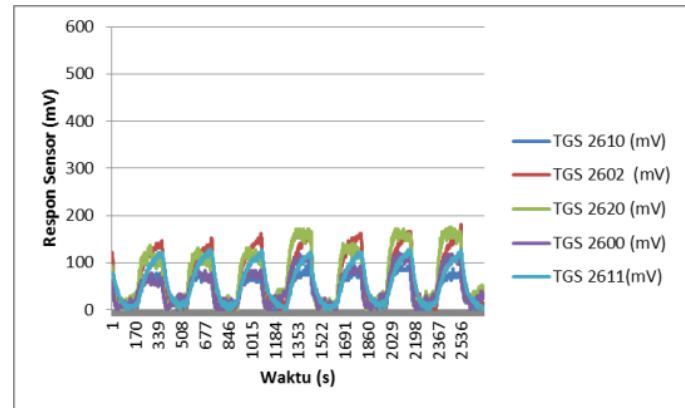

(a)

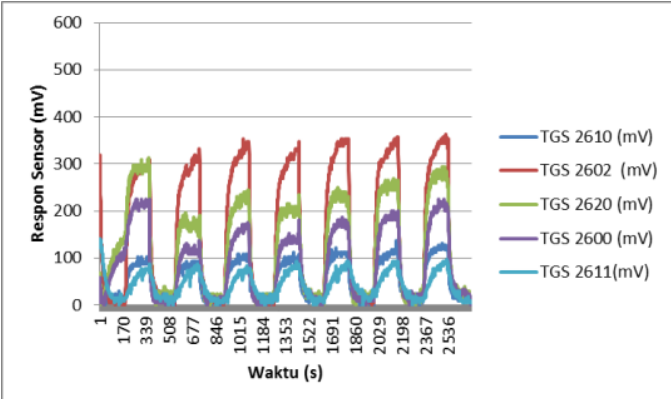

(c)

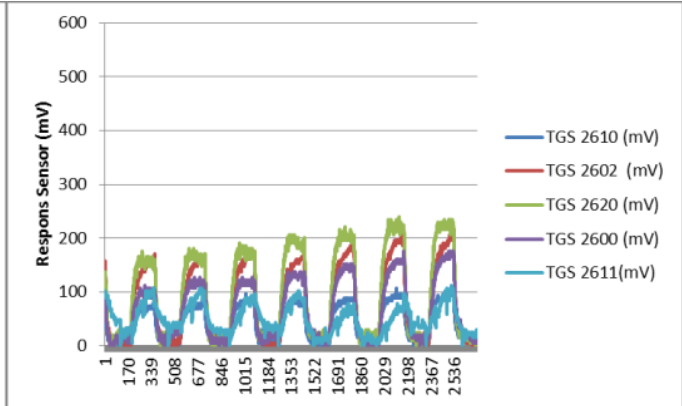

(b)

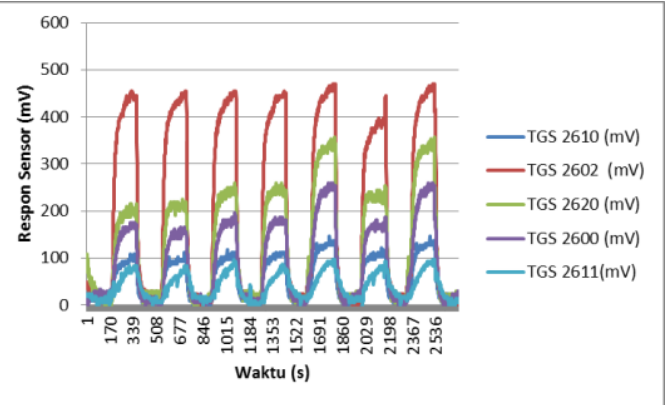

(d)

Gambar 2 Grafik respon sensor daging babi campuran (a) 20\%, (b) 40\%, (c) 60\%, dan (d) $80 \%$

Berdasarkan Gambar 1 dan Gambar 2 terlihat respon sinyal masing-masing sensor terhadap aroma dari keenam sampel daging. Aroma sampel daging babi mempunyai hasil pembacaan sensor tertinggi daripada sampel daging yang lainnya. Hal ini menunjukkan bahwa daging babi mempunyai ciri yang kuat, seperti yang ditampilkan pada Gambar 2 grafik daging babi campuran dengan persentase daging babi yang semakin tinggi hasil bacaan sensornya semakin tinggi pula ditunjukkan pada Gambar 2 (b) yaitu respon sensor dari sampel dengan kandungan daging babi $80 \%$ mempunyai respon bacaan sensor yang lebih tinggi daripada daging campuran yang lainnya.

\subsection{Prapemrosesan Sinyal}

Prapemrosesan sinyal terdiri dari dua proses yaitu manipulasi baseline dan ekstraksi ciri. Proses manipulasi baseline dilakukan untuk mengurangi penyimpangan pada respon sensor dan mengatasi pergeseran nilai baseline dengan menyamakan baseline masing masing sensor. Sinyal respon sensor yang belum dilakukan proses manipulasi baseline ditunjukkan pada Gambar 3, sedangkan sinyal respon sensor yang sudah dilakukan manipulasi baseline ditunjukkan pada Gambar 4. 


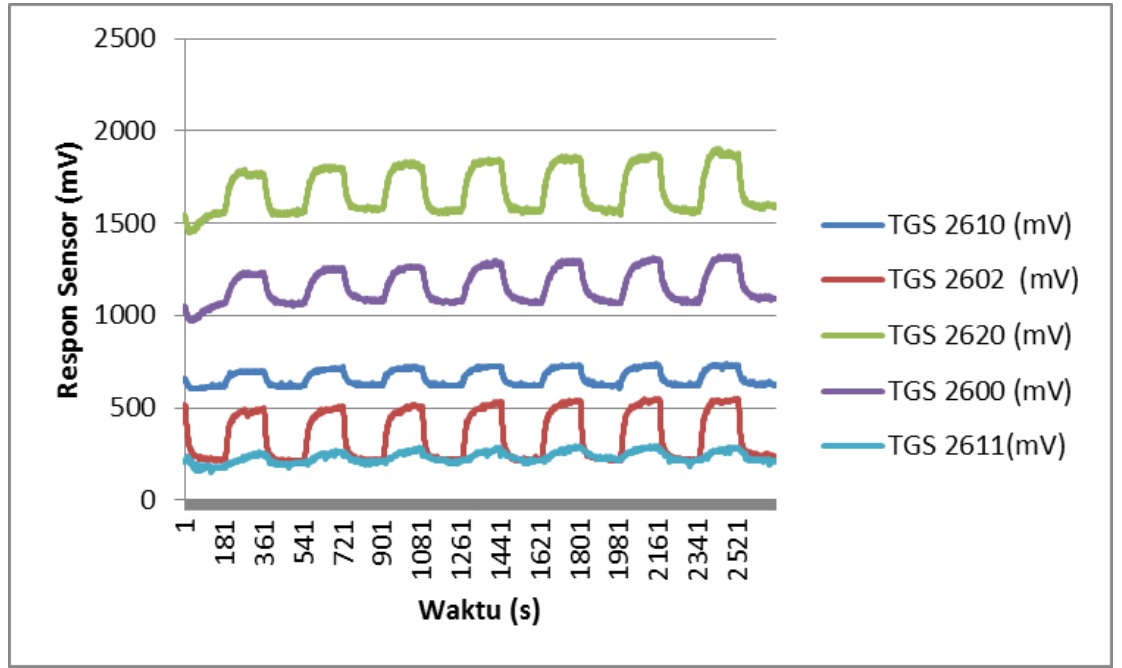

Gambar 3 Respon Sensor Tanpa Prapemrosesan Sinyal

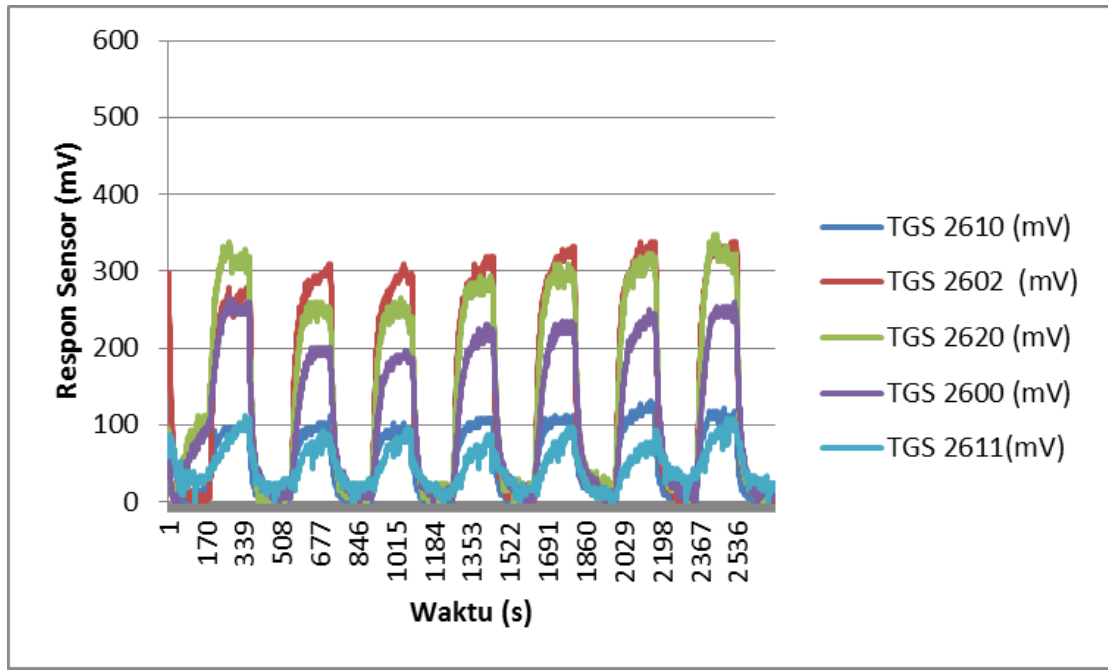

Gambar 4 Respon sensor setelah prapemrosesan sinyal

Tahap selanjutnya adalah ekstraksi ciri, proses ekstraksi ciri digunakan untuk mengambil data penting informasi penting dari keseluruhan data hasil pembacaan sensor. Informasi penting hasil ekstraksi ciri ini mewakili karakteristik dari data sampelnya. Proses ekstraksi ciri ini dilakukan dengan 2 metode yaitu integral dan difference. Proses ekstraksi ciri integral dengan menghitung luasan tiap kurva dari respon sinyal setelah dilakukan manipulasi baseline, sedangkan proses ekstraksi ciri difference dengan menghitung selisih nilai maksimum dan minimumnya dari tiap kurva respon sinyal.

\subsection{Hasil Pengujian dengan BAM}

Pengujian ini digunakan untuk menguji keberhasilan dari program yang dibuat untuk mendeteksi daging sapi dengan daging yang lainnya. Pengujian program dengan data yang sudah digunakan pada penelitian sebelumnya dilakukan terlebih dahulu untuk mengetahui program yang dibuat sesuai dengan algoritmanya. Data dibawah ini digunakan sebagai data masukan dan targetnya. 


$$
\begin{array}{ll}
A_{1}=(100111000), & B_{1}=(111000010) \\
A_{2}=(011100111), & B_{2}=(100000001) \\
A_{3}=(101011011), & B_{3}=(010100101) .
\end{array}
$$

Data A akan digunakan sebagai data acuan dan data B digunakan sebagai target, kemudian dimasuk ke layer $(\mathrm{x}, \mathrm{y})$ dengan diubah menjadi bipolar seperti dibawah ini.

$$
\begin{aligned}
& X_{1}=(1-1-11111-1-1-1) \text {, } \\
& Y_{1}=\left(\begin{array}{lllllllll}
1 & 1 & 1 & -1 & -1 & -1 & -1 & 1 & -1
\end{array}\right) \text {, } \\
& X_{2}=\left(\begin{array}{lllllllll}
-1 & 1 & 1 & 1 & -1 & -1 & 1 & 1 & 1
\end{array}\right) \text {, } \\
& Y_{2}=(1-1-1-1-1-1-1-11) \text {, } \\
& X_{3}=\left(\begin{array}{lllllllll}
1 & -1 & 1 & -1 & 1 & 1 & -1 & 1 & 1
\end{array}\right), \\
& Y_{3}=\left(\begin{array}{lllllllll}
-1 & 1 & -1 & 1 & -1 & -1 & 1 & -1 & 1
\end{array}\right) \text {. }
\end{aligned}
$$

Data tersebut diujikan pada program yang sudah dibuat dalam bentuk matriks $3 \times 3$ pada

\begin{tabular}{|c|c|c|c|c|c|c|}
\hline No Percobaan & Data Acuan 1 & Data Acuan 2 & Data Acuan 3 & Data Uji & Hasil I & | Kebenaran | \\
\hline 1 & a11 & a2 1 & a3 1 & a12 & a1 & 1 \\
\hline 1 & a11 & a2 1 & a3 1 & a13 & a1 & 1 \\
\hline 1 & a11 & a2 1 & a3 1 & a2 2 & a2 & 1 \\
\hline 1 & a11 & a2 1 & a3 1 & a2 3 & a2 & 1 \\
\hline 1 & a1 1 & a2 1 & a3 1 & a3 2 & a3 & 1 \\
\hline 1 & a11 & a2 1 & a3 1 & a3 3 & a3 & 1 \\
\hline 2 & a1 1 & a2 1 & a3 2 & a12 & a1 & 1 \\
\hline 2 & a11 & a2 1 & a3 2 & a13 & a1 & 1 \\
\hline 2 & a1 1 & a2 1 & a3 2 & a2 2 & a2 & 1 \\
\hline 2 & a1 1 & a2 1 & a3 2 & a2 3 & a2 & 1 \\
\hline 2 & a1 1 & a2 1 & a3 2 & a3 1 & a3 & 1 \\
\hline 2 & a1 1 & a2 1 & a3 2 & a3 3 & a3 & 1 \\
\hline 3 & a11 & a2 1 & a3 3 & a12 & a1 & 1 \\
\hline 3 & a11 & a2 1 & a3 3 & a13 & a1 & 1 \\
\hline 3 & a1 1 & a2 1 & a3 3 & a2 2 & $a 2$ & 1 \\
\hline- & $=$ & $\cdots$ & $=0$ & $\sim$ & 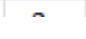 & -1 \\
\hline
\end{tabular}
data masukannya sedangkan data targetnya dalam matriks $3 \times 9$. Cuplikan hasil pengujian yang dilakukan berdasarkan data dari referensi ditunjukkan oleh Tabel 1. Berdasarkan hasil yang ditunjukkan Tabel 1, program dapat mendeteksi data uji berdasarkan dari data acuan yang diberikan dengan tingkat keberhasilan proses deteksi sebesar $100 \%$. Pengujian dilakukan sebanyak 162 kali dengan 27 macam data acuan dan data ujinya, berdasarkan persentasi keberhasilan pengujian yang sesuai dengan referensi dapat disimpulkan bahwa program yang dibuat sudah sesuai dengan algoritma Bidirectional Assocative Memory (BAM).

Tabel 1 Cuplikan Hasil Pengujian dengan Data Referensi

Hasil keberhasilan deteksi daging dengan data hasil ekstraksi ciri integral untuk perubahan ke bipolar cara pertama didapatkan persentase keberhasilan 14,8\%, dengan 1296 deteksi berhasil dari 8748 percobaan. Sedangkan dengan perubahan bipolar menggunakan cara kedua didapatkan persentase keberhasilan 15,7\% dengan 1377 deteksi berhasil dari 8748. Nilai keberhasilan dengan perubahan ke bipolar dengan cara kedua lebih tinggi dipengaruhi perbedaan pola matriks antar sampel dari cara perubahan ke bipolar dengan cara kedua menghasilkan perbedaan yang lebih banyak antara satu dampel daging dengan sampel daging yang lainnya 
Hasil keberhasilan deteksi daging dengan data hasil ekstraksi ciri difference untuk perubahan ke bipolar cara pertama didapatkan persentase keberhasilan 17,3\%, dengan 1512 deteksi berhasil dari 8748 percobaan. Sedangkan dengan perubahan bipolar menggunakan cara kedua didapatkan persentase keberhasilan 16,4\% dengan 1431 deteksi berhasil dari 8748. Nilai keberhasilan dengan perubahan ke bipolar dengan cara pertama lebih tinggi, hal ini dipengaruhi perbedaan pola matriks antar sampel yaitu perubahan ke bipolar dengan cara pertama menghasilkan perbedaan yang lebih banyak antara satu sampel daging dengan sampel daging yang lainnya.

Hasil pengujian yang didapatkan dengan keseluruhan data yang dilakukan dapat diketahui persentase keberhasilan deteksi terbaik sebesar $17,3 \%$ yaitu dengan ekstraksi ciri difference yang diubah menjadi pola matriks dengan cara pertama. Hal tersebut menunjukkan bahwa metode ekstraksi ciri mempunyai pengaruh terhadap hasil deteksi, selain itu proses perubahan ke bipolar sesuai dengan ketentuan algoritma BAM juga mempunyai pengaruh terhadap pola matriks bipolar yang dihasilkan. Pola matriks yang dihasilkan ini dipengaruhi juga dengan penentuan threshold yang menjadi nilai batas dalam mengubah nilai hasil ekstraksi ciri ke bipolar.

Berdasarkan hasil pengujian dari program BAM yang ditunjukkan pada Tabel 2 terdapat hasil deteksi yang tidak sesuai dengan data ujinya, hal ini disebabkan deteksi data uji dilakukan namun dari data acuan yang digunakan tidak sesuai pada saat pertama kali dilalukan deteksi, sehingga dilakukan perbaikan lapisan input namun menghasilkan hasil deteksi data yang lain berdasarkan data acuannya. Hal tersebut merupakan kemampuan dari BAM yang dapat mendeteksi data uji dengan melakukan perbaikan data lapisan input sehingga dapat dilakukan deteksi meskipun hasilnya terdapat kesalahan yaitu hasil deteksi berbeda dengan data ujinya.

Tabel 2 Cuplikan Hasil Pengujian BAM dari Data Ekstraksi Ciri

\begin{tabular}{|c|c|c|c|c|c|c|c|c|c|}
\hline \multicolumn{2}{|c|}{ No Percok Data Acuan 1} & Data Acuan 2 & Data Acuan 3 & Data Acuan 4 & Data Acuan 5 & Data Acuan 6 & Data Uji & Hasil Deteksi & Kebenaran \\
\hline 1 & Sapi 1 & Babi $20 \% 1$ & Babi $40 \% 1$ & Babi $60 \% 1$ & Babi $80 \% 1$ & Babi 1 & Sapi 2 & Sapi & 1 \\
\hline 1 & Sapi 1 & Babi $20 \% 1$ & Babi $40 \% 1$ & Babi $60 \% 1$ & Babi $80 \% 1$ & Babi 1 & Sapi 3 & Sapi & 1 \\
\hline 1 & Sapi 1 & Babi $20 \% 1$ & Babi $40 \% 1$ & Babi $60 \% 1$ & Babi $80 \% 1$ & Babi 1 & Babi $20 \%$ & Sapi & 0 \\
\hline 1 & Sapi 1 & Babi $20 \% 1$ & Babi $40 \% 1$ & Babi $60 \% 1$ & Babi $80 \% 1$ & Babi 1 & Babi $20 \%$ & Sapi & 0 \\
\hline 1 & Sapi 1 & Babi $20 \% 1$ & Babi $40 \% 1$ & Babi $60 \% 1$ & Babi $80 \% 1$ & Babi 1 & Babi $40 \%$ & Sapi & 0 \\
\hline \multirow{19}{*}{$\begin{array}{l}728 \\
728 \\
728 \\
729 \\
729 \\
729 \\
729 \\
729 \\
729 \\
729 \\
729 \\
729 \\
729 \\
729 \\
729\end{array}$} & $\ldots$ & $\ldots$ & $\ldots$ & $\ldots$ & $\ldots$ & $\ldots$ & $\ldots$ & $\ldots$ & $\ldots$ \\
\hline & Sapi 3 & Babi $20 \% 2$ & Babi $40 \% 3$ & Babi $60 \% 2$ & Babi $80 \% 3$ & Babi 2 & Babi $80 \%$ & Babi $60 \%$ & 0 \\
\hline & Sapi 3 & Babi $20 \% 2$ & Babi $40 \% 3$ & Babi $60 \% 2$ & Babi $80 \% 3$ & Babi 2 & Babi 1 & Babi $60 \%$ & 0 \\
\hline & Sapi 3 & Babi $20 \% 2$ & Babi $40 \% 3$ & Babi $60 \% 2$ & Babi $80 \% 3$ & Babi 2 & Babi 3 & Babi $60 \%$ & 0 \\
\hline & Sapi 3 & Babi $20 \% 3$ & Babi $40 \% 3$ & Babi $60 \% 3$ & Babi $80 \% 3$ & Babi 3 & Sapi 1 & Babi $40 \%$ & 0 \\
\hline & Sapi 3 & Babi $20 \% 3$ & Babi $40 \% 3$ & Babi $60 \% 3$ & Babi $80 \% 3$ & Babi 3 & Sapi 2 & Babi $40 \%$ & 0 \\
\hline & Sapi 3 & Babi $20 \% 3$ & Babi $40 \% 3$ & Babi $60 \% 3$ & Babi $80 \% 3$ & Babi 3 & Babi $20 \%$ & Babi $40 \%$ & 0 \\
\hline & Sapi 3 & Babi $20 \% 3$ & Babi $40 \% 3$ & Babi $60 \% 3$ & Babi $80 \% 3$ & Babi 3 & Babi $20 \%$ & Babi $40 \%$ & 0 \\
\hline & Sapi 3 & Babi $20 \% 3$ & Babi $40 \% 3$ & Babi $60 \% 3$ & Babi $80 \% 3$ & Babi 3 & Babi $40 \%$ & Babi $40 \%$ & 1 \\
\hline & Sapi 3 & Babi $20 \% 3$ & Babi $40 \% 3$ & Babi $60 \% 3$ & Babi $80 \% 3$ & Babi 3 & Babi $40 \%$ & Babi $40 \%$ & 1 \\
\hline & Sapi 3 & Babi $20 \% 3$ & Babi $40 \% 3$ & Babi $60 \% 3$ & Babi $80 \% 3$ & Babi 3 & Babi $60 \%$ & Babi $40 \%$ & 0 \\
\hline & Sapi 3 & Babi $20 \% 3$ & Babi $40 \% 3$ & Babi $60 \% 3$ & Babi $80 \% 3$ & Babi 3 & Babi $60 \%$ & Babi $60 \%$ & 1 \\
\hline & Sapi 3 & Babi $20 \% 3$ & Babi $40 \% 3$ & Babi $60 \% 3$ & Babi $80 \% 3$ & Babi 3 & Babi $80 \%$ & Babi $40 \%$ & 0 \\
\hline & Sapi 3 & Babi $20 \% 3$ & Babi $40 \% 3$ & Babi $60 \% 3$ & Babi $80 \% 3$ & Babi 3 & Babi $80 \%$ & Babi $60 \%$ & 0 \\
\hline & Sapi 3 & Babi $20 \% 3$ & Babi $40 \% 3$ & Babi $60 \% 3$ & Babi $80 \% 3$ & Babi 3 & Babi 1 & & 0 \\
\hline & Sapi 3 & Babi $20 \% 3$ & Babi $40 \% 3$ & Babi $60 \% 3$ & Babi $80 \% 3$ & Babi 3 & Babi 2 & & 0 \\
\hline & & & & & & & & & 1431 \\
\hline & & & & & & & & & \\
\hline & & & & & & & & & $16,40 \%$ \\
\hline
\end{tabular}

Pengujian yang dilakukan dalam penelitian ini tidak hanya untuk keseluruhan sampel saja, tetapi juga pengujian dengan 2 sampel saja. Hal ini bertujuan untuk mendapatkan informasi mengenai tingkat keberhasilan dari sistem jika menggunakan 2 data sampel saja seperti yang ditunjukkan oleh Tabel 3 dan Tabel 4. 
Tabel 3 Pengujian dengan 2 Sampel dari Ekstraksi Ciri Integral

\begin{tabular}{|l|c|c|}
\hline \multicolumn{1}{|c|}{ Data } & Bipolar Cara 1 & Bipolar Cara 2 \\
\hline Sapi vs Babi & $23,1 \%$ & $23,1 \%$ \\
\hline Sapi vs Babi 20\% & $69,4 \%$ & $44,4 \%$ \\
\hline Sapi vs Babi 40\% & $52,8 \%$ & $41,7 \%$ \\
\hline Sapi vs Babi 60\% & $36,1 \%$ & $38,9 \%$ \\
\hline Sapi vs Babi 80\% & $30,6 \%$ & $33,3 \%$ \\
\hline
\end{tabular}

Tabel 4 Pengujian dengan 2 Sampel dari Ekstraksi Ciri Difference

\begin{tabular}{|l|c|c|}
\hline \multicolumn{1}{|c|}{ Data } & Bipolar Cara 1 & Bipolar Cara 2 \\
\hline Sapi vs Babi & $13,9 \%$ & $13,9 \%$ \\
\hline Sapi vs Babi $20 \%$ & $52,8 \%$ & $41,7 \%$ \\
\hline Sapi vs Babi 40\% & $47,2 \%$ & $55,6 \%$ \\
\hline Sapi vs Babi 60\% & $27,8 \%$ & $52,8 \%$ \\
\hline Sapi vs Babi 80\% & $36,1 \%$ & $36,1 \%$ \\
\hline
\end{tabular}

Berdasarkan Tabel 3 nilai persentase keberhasilan deteksi daging dengan nilai persentase tertinggi saat dilakukan pengujian sampel daging sapi dan daging campuran babi $20 \%$ sebesar $69,4 \%$ dengan 25 deteksi berhasil dari 36 percobaan. Data dari kedua sampel tersebut diolah dengan metode ekstraksi ciri integral yang kemudian diubah menjadi bipolar dengan cara pertama, sedangkan nilai persentase keberhasilan paling rendah saat dilakukan pengujian sampel daging sapi dan daging babi yaitu sebesar 23,1\% dengan 8 deteksi berhasil dari 36 percobaan dilakukan pengubaan bipolar dengan cara pertama maupun kedua

Berdasarkan Tabel 4 nilai persentase keberhasilan deteksi daging dengan nilai persentase tertinggi saat dilakukan pengujian sampel daging sapi dan daging campuran babi 40\% sebesar 55,6\% dengan 20 deteksi berhasil dari 36 percobaan. Data dari kedua sampel tersebut diolah dengan metode ekstraksi ciri difference yang kemudian diubah menjadi bipolar dengan cara kedua

\section{KESIMPULAN}

Berdasarkan penelitian yang telah dilakukan maka dapat diambil kesimpulan sebagai berikut

1. Deteksi daging sapi dengan Bidirectional Associative Memory yang menggunakan ekstraksi ciri integral menghasilkan persentase keberhasilan $14,8 \%$ dengan perubahan bipolar cara pertama, menghasilkan persentase keberhasilan $15,7 \%$ dengan perubahan bipolar cara kedua.

2. Deteksi daging sapi dengan Bidirectional Associative Memory yang menggunakan ekstraksi ciri difference menghasilkan persentase keberhasilan 17,3\% dengan perubahan bipolar cara pertama, menghasilkan persentase keberhasilan 16,4\% dengan perubahan bipolar cara kedua.

3. Ada pengaruh dari penentuan nilai threshold terhadap perubahan data menjadi bipolar dan juga keberhasilan deteksi. 


\section{SARAN}

Saran yang disampaikan penulis untuk pengembangan penelitian yang akan datang adalah sebagai berikut

1. Dilakukan ekstraksi ciri dengan metode lain untuk mengetahui pengaruhnya terhadap hasil deteksi.

2. Dilakukan penelitian terhadap penentuan nilai threshold untuk mencari cara yang paling tepat dan efektif.

3. Dilakukan penelitian dengan metode BAM untuk sampel lain.

\section{DAFTAR PUSTAKA}

[1]Harmini, R. W. Asmarantaka, J. Atmakusuma, "Model Dinamis Sistem Ketersediaan Daging Sapi Nasional,” Jurnal Ekonomi Pembangunan, vol. 12, no. 1, pp. 128-146, Juni 2011.

[2] E. Budianita, Jasril, L. Handayani, "Implementasi Pengolahan Citra dan Klasifikasi KNearest Neighbour untuk Membangun Aplikasi Pembeda Daging Sapi dan Babi," Jurnal Sains Teknologi dan Industri, vol. 12, no. 2, pp. 242-247, Juni 2015.

[3]L. Hilda, "Analisis Kandungan Lemak Babi dalam Produk Pangan Di Padangsidimpuan Secara Kualitatif dengan Menggunakan Gas Kromatografi (GC)," Tazkir, vol. 9, pp. 1-15. 2014.

[4]K. Triyana, D.K. Agustika, F. Hardoyono, and Chotimah, "Penerapan Metode Ekstraksi Ciri Berbasis Transformasi Wavelet Diskrit untuk Meningkatkan Unjuk Kerja Electronic nose," Prosiding Pertemuan Ilmiah XXVI HFI Jateng \& DIY, Purworejo, pp. 90-93, Apr. 2012.

[5]D. Lelono , K. Triyana, S. Hartati, and J.E. Istiyanto, "Development of Electronic Nose with Highly Stable Sample Heater to Classify Quality Levels of Local Black Tea," International Journal Of Advanced Science Engineering Information Technology, vol. 7, no. 2, pp. 352358, 2017.

[6]T. Sutojo, E. Mulyanto, V. Suhartono, Kecerdasan Buatan. Yogyakarta, Indonesia: Penerbit Andi, 2010.

[7]Y. Kurniati, "Implementasi Metode Bidirectional Associative memory pada Absensi Berbasis Indentifikasi Wajah,” S.Kom Skripsi, Ilmu Komputer, Universitas Sumatra Utara, Indonesia, 2014.

[8]F. Rosyad and D. Lenono, "Klasifikasi Kemurnian Daging Sapi Berbasis Electronic Nose dengan Metode Principal Component Analysis," IJEIS (Indonesian J. Electron. Instrum. Syst., vol. 6, no. 1, p. 47, Apr. 2016 [Online]. Available: https://jurnal.ugm.ac.id/ijeis/article/view/10770. [Accessed: 31-May-2017]

[9]I. Hornstein and P. F. Crowe, "Meat Flavor Chemistry, Flavor Studies on Beef and Pork," J. Agric. Food Chem., vol. 8, no. 6, pp. 494-498, Nov. 1960.

[10] A.J. Myers, S.M. Scramlin, A.C. Dilger, C.M. Souza, F.K. McKeith, and J. Killefer, "Contribution of lean, fat, muscle color and degree of doneness to pork and beef species flavor," Jurnal of Meat Science, vol. 82, p. 59, Dec. 2008.

[11] C. A. Lintang, T. W. Widodo, and D. Lelono, "Rancang Bangun Electronic Nose untuk Mendeteksi Tingkat Kebusukan Ikan Air Tawar," IJEIS (Indonesian J. Electron. Instrum. Syst., vol. 6, no. 2, p. 129, Oct. 2016 [Online]. Available: https://jurnal.ugm.ac.id/ijeis/article/view/15251. [Accessed: 31-May-2017]

[12]B. Kosko, "Bidirectional Associative Memories," IEEE Trans. Syst. Man. and Cybern., vol. 18, no. 1, pp. 49-60, Feb. 1988. 